\title{
KOŚCIÓŁ SURB SARGIS W TEKOR W ARMENII. MIĘDZY PERSJĄ A BIZANCJUM
}

Niewielka miejscowość Tekor, pojawiająca się na niektórych mapach również pod nazwą Digor, leży obecnie na wschodnich rubieżach Turcji, w wilajecie Kars, nieopodal rzeki Achurian, która wyznacza granicę z Republiką Armenii. W starożytności i w okresie średniowiecza tereny te stanowiły centrum historycznych i etnicznych ziem armeńskich. Rozciągała się tu prowincja Szirak, szczególnie aktywna od połowy IX do końca XI w., a więc w czasach Królestwa Bagratydów, którego stolicą było wielkie miasto Ani, oddalone od Tekor o kilkanaście kilometrów w kierunku północno-wschodnim.

Kościół Surb Sargis (św. Sergiusza) jest dzisiaj kompletną ruiną. Zanim uległ sukcesywnej destrukcji zapoczątkowanej przez trzęsienie ziemi w $1911 \mathrm{r}$. został poddany dosyć gruntownym badaniom, które pozwoliły dostrzec w nim jedną z najważniejszych budowli z epoki wczesnochrześcijańskiej. O wyjątkowym znaczeniu obiektu decyduje kilka przyczyn. Przede wszystkim świątynia odznaczała się oryginalnym układem przestrzennym, podporządkowanym kopule - czy raczej konstrukcji o charakterze kopułowym - ponad centralnym przęsłem. Dla jej posadowienia zastosowano ciekawe rozwiązanie techniczne, wprawdzie jeszcze niedoskonałe, niewattpliwie jednak nowatorskie. Ponadto kościół jest precyzyjnie datowany, co wśród ówczesnych budowli armeńskich należy do rzadkości. Dzięki temu w wielu wypadkach mógł służyć jako punkt odniesienia przy datowaniu innych obiektów.

Jednak wyjątkowego znaczenia kościoła w Tekor nie można - moim zdaniem - zamknąć w obrębie dziedzictwa architektonicznego samej tylko Armenii. Uważam, że budowla jest jednym z najlepszych, a przy tym jednym z najwcześniejszych ogniw w procesie wykształcania się krzyżowo-kopułowego układu świątyń, który zdominował architekturę sakralną całej wschodniej części Orbis Christianus. Z inżynieryjnego punkty widzenia krzyżowo-kopułowy typ kościoła był realizacją ambitną. Tym samym przysparzał poważnych trudności. Obecnie w badaniach naukowych panuje w zasadzie zgodność, że znaczny wkład w rozwiązywaniu tych problemów miały inspiracje, które napływały na obszary chrześcijańskie z krajów ościennych,

* Dr Daniel Próchniak - były pracownik Instytutu Historii Sztuki na Wydziale Nauk Humanistycznych Katolickiego Uniwersytetu Lubelskiego Jana Pawła II; e-mail: proch953@gmail.com. 
konkretnie z Persji. W osmozie tej Armenia odegrała rolę szczególną jako teren tranzytowy. Szybko i na trwałe schrystianizowana, wcześniej jednak przez wieki silnie związana z perską tradycją cywilizacyjna, czerpała z partyjskiego i sasanidzkiego dorobku budowlanego, by przyswojone rozwiązania przekazać sąsiadom, budowniczym gruzińskim, a zwłaszcza bizantyńskim.

1. Stan badań nad obiektem początkuje dwutomowa praca Charlesa Texiera, wydana w Paryżu w latach 1842-1852. Ta typowa dla ówczesnego charakteru badań publikacja - na poły podróżnicza, na poły naukowa - dziś posiada przede wszystkim wartość ikonograficzną. Oprócz krótkiego opisu kościoła ${ }^{2}$, znalazła się w niej grawiura przedstawiająca wygląd budowli około połowy XIX w. (il. 1) oraz kilka starannie wykonanych rysunków ukazujących m.in. architektoniczne przekroje i detale. W niektórych szczegółach ilustracje te nie były jednak zgodne ze stanem faktycznym, czego dowiodły prace przeprowadzone pod koniec XIX i w pierwszych latach XX stulecia przez Torosa Toramanjan $^{3}$, pioniera profesjonalnych już badań nad architekturą armeńską. Wykonał on pomiary kościoła oraz przedstawił analizę faz konstrukcyjnych, połączoną ze śmiałą interpretacją najwcześniejszej fazy budowli jako świątyni pogańskiej. Oczywiście nie wszystkie ustalenia Toramanjana wytrzymały próbę czasu, mimo to publikacja nadal posiada dużą wartość faktograficzną. Autor był bowiem jedynym uczonym, któremu dane było przeprowadzenie badań przed wspomnianym trzęsieniem ziemi, w czasach, w których kościół znajdował się nie tylko w dobrym stanie, ale służył nadal celom liturgicznym (il. 2). Siłą rzeczy zebrane wówczas informacje stały się podstawą w dalszych pracach nad obiektem.

Spośród współczesnych Toramanjanowi wymienić należy jeszcze dwóch uczonych. Nikołaj Marr ${ }^{4}$ skoncentrował się głównie na datowaniu kościoła oraz podjął problem jego wezwania. Będąc orientalistą, architekturze poświęcił jednak niewiele uwagi. Natomiast Josef Strzygowski ${ }^{5}$ przedstawił syntezę ówczesnej wiedzy na temat obiektu w oparciu o poglądy Toramanjana, jak również, powołując się na wspomnianą pracę Marra, analizę i interpretację inskrypcji w portalu zachodnim oraz problemy związane z przekształceniem kościoła w budowlę kopułową. Warto dodać, że Strzygowski był ostatnim badaczem, który w trakcie swych bliskowschodnich podróży ujrzał kościół

${ }^{1}$ Ch.F.M. Texier, Description de l'Arménie, de la Perse et de la Mésopotamie. Géographie, géologie, monuments anciens et modernes, I-II, Paris 1842-1852.

${ }^{2}$ Por. tamże, I, s. 120 n.

${ }^{3}$ Por. T. Toramanjan, Nyut'er Hayakakan čartarapetut'yan patmut'yan (Materiaty do historii architektury Armenii; w j. armeńskim), I, Erevan 1942, 185-220, podaję za: A. Khatchatrian, Architecture arménienne du $I V^{e}$ au $V I^{e}$ siècle, Paris 1971, 48.

${ }^{4}$ Por. Н.Я. Марр, К датировке ктиторской надписи Текорского храма, „Христянский Восток" 3 (1914) 56-71.

${ }^{5}$ Por. J. Strzygowski, Die Baukunst der Armenier und Europa, I, Wien 1918, 39-41, 335-341 i 370n. 
w Tekor w postaci wprawdzie już zrujnowanej, pozwalającej jednak na odtworzenie struktury przestrzennej, poznanie rozwiązań technicznych i dekoracji architektonicznej. Świadczą o tym liczne rysunki i fotografie w jego monumentalnym Die Baukunst der Armenier und Europa, wydanym w Wiedniu w 1918 r. (il. 3). Stan taki przetrwał do ok. połowy XX stulecia ${ }^{6}$. Późniejsi badacze mogli oglądać jedynie mało czytelne ruiny ${ }^{7}$.

Okres badań po II wojnie światowej rozpoczyna praca z 1946 r. (II wydanie poprawione ukazało się w roku 1961), autorstwa Nikołaja Tokarskiego ${ }^{8}$, który jedynie skrótowo przedstawił ustalenia poprzedników. Istotny wkład w studia nad obiektem wniosły dopiero dwie nowsze publikacje - Armena Khatchatriana z 1971 r. ${ }^{9}$ i Francesco Gandolfo z roku $1982^{10}$.

2. Źródła pisane związane z kościołem sprowadzają się do licznych inskrypcji wyrytych w różnych epokach w różnych miejscach budowli. M.in. cztery napisy zachowały się w portalu zachodnim (il. 4). Trzy spośród nich - pochodzące z początku IX w. - wypełniały pole tympanonu, informując o zniesieniu podatków i uwolnieniu poddanych przez władców bagratydzkich, ich treść jest zatem dla nas drugorzędna. Szczególną wartość przedstawiała natomiast czwarta, pięciowersowa inskrypcja umieszczona na belce nadproża. Miała ona ciekawą, wręcz zagadkową formę - litery w poszczególnych linijkach różniły się wielkością, a ponadto należało ją czytać w odwrotnej kolejności, to znaczy poczynając od wersu najniższego ku górze. Treść inskrypcji jest następująca:

1. (5) Sahak Kamsarakan zbudował to martyrium

2. (4) świętego Sargisa

3. (3) dla zapewnienia łaski dla siebie, dla swojej rodziny, dla żony, synów, przyjaciół, braci

4. (2) a miejsce to ofiarował/ufundował Hovhan, katolikos Armeńczyków i Hovhan

5. (1) biskup i Taron, przełożony klasztoru i Manan zarządca i Uran, który...11.

W tym miejscu napis się urywa. Jak widzimy inskrypcja nie zawierała żadnej daty, dlatego w celu czasowego jej przyporządkowania konieczne jest zidentyfikowanie wymienionych postaci.

\footnotetext{
${ }^{6}$ Por. P. Cuneo, Architettura armena dal quarto al diciannovesimo secolo, I, Roma 1988, 642-664.

${ }^{7}$ Por. N. Thierry - M. Thierry, Notes sur des monuments arméniens en Turquie (1964), REArm NS 2 (1965) 171.

${ }^{8}$ Por. Н. Токарский, Архитектура древней Армении, Ереван 1961, 82n.

${ }^{9}$ Por. Khatchatrian, Architecture arménienne, s. 48-53.

${ }^{10}$ Por. F. Gandolfo, Le basiliche armene IV-VII secolo, Studi di Architettura Medioevale Armena 5, Roma 1982, 20-27.

11 Cyt. za: A. Khatchatrian, Inscriptions et histoire des églises arméniennes, Ricerca sull'architettura armena 8, Milano 1974, 89, thum. własne.
} 
Łazarz z Farpi, opisując w Patmut'iwn Hayoc' wydarzenia 2. poł. V w., wspomina o trzech braciach z rodu Kamsarakanów (71), a w innym miejscu o trzech Kamsarakanach, synach Arszawira $(73)^{12}$. W jeszcze innych fragmentach znajdujemy ich imiona: Nerseh, książę Sziraku, Hrahad (59) oraz Sahak $(76)^{13}$. Pamiętając, że Tekor leży właśnie w Sziraku, możemy przyjąć, że wymienieni w inskrypcji fundator i jego bracia to Sahak, Nerseh i Hrahad Kamsarakanowie z przekazu Łazarza, bardzo aktywni uczestnicy walk niepodległościowych przeciw Persji prowadzonych w początkach 80-tych lat V w. Łazarz wspomina także dwukrotnie (59 i 85) ${ }^{14}$ Hovhanesa z rodu Mandakunich, współczesnego tym wydarzeniom, który był katolikosem Armenii w latach 478-504 ${ }^{15}$. A zatem możemy przyjąć z dużym prawdopodobieństwem, że fundacja kościoła przez Sahaka Mamsarakana miała miejsce w ostatniej ćwierci V w., najdalej w pierwszych latach VI stulecia.

3. Architektura. W postaci znanej z przełomu XIX i XX w. kościół Surb Sargis stał na wysokiej, 9-stopniowej krepidomie, dokładnie odpowiadającej w swym obrysie kształtowi wszystkich elementów tworzących jego bryłę (il. 5). Zasadniczy korpus składał się z trzech naw podzielonych na trzy przęsła dwiema parami filarów. Nawę główną, zdecydowanie szerszą od bocznych, zamykała od wschodu głęboka, podkowiasta w planie absyda, prawie całkowicie ukryta $\mathrm{w}$ masywie murów. Było to zgodne $\mathrm{z}$ wczesnochrześcijańska, a także późniejszą, armeńską tradycją budowlaną ${ }^{16}$. Od strony zewnętrznej absydę akcentował jedynie stosunkowo płaski, trójboczny ryzalit. Absydę flankowały dwa wąskie, prostokątne pomieszczenia, skomunikowane z nawami bocznymi i zdecydowanie występujące ku północy i południowi w stosunku do lica bocznych elewacji korpusu. Pomieszczenie północne posiadało niewielką podkowiasta eksedrę, otwartą arkadowo w kierunku zachodnim (il. 6). Niektórzy badacze wskazują na baptyzmalną jej funkcję, co wydaje mi się wątpliwe. Szerokość ukształtowanej w ten sposób części wschodniej kościoła pokrywała się dokładnie z szerokością najwyższego stopnia krepidomy, czego nie można powiedzieć o pozostałych częściach budowli, znacznie cofniętych w stosunku do krawędzi stylobatu. Pozwoliło to na wzniesienie trzech portyków obiegających korpus kościoła od północy, zachodu i południa. Wskazują na to liczne pilastry i kolumny uwięzłe w licach ścian. Wysokość tych podpór dochodziła do około $2 / 3$ wysokości wieńca murów, z czego możemy

${ }^{12}$ Por. w przekładzie francuskim: Lazare de Pharbe, Historie de l'Arménie, trad. S. Ghésarian, w: Collection des Historiens ancient et morernes de l'Arménie, publiée par V. Langlois, II, Paris, 1869,348 i $351 \mathrm{n}$.

${ }^{13}$ Por. tamże, s. 329 i 365.

${ }^{14}$ Por. tamże.

${ }^{15}$ Por. R. Grousset, L'Histoire de l'Arménie des origins jusqu'à 1071, Paris 1947, 217.

${ }^{16}$ Szerzej na temat absyd w architekturze armeńskiej por. D. Próchniak, Wczesnochrześcijański kościót Surb Połos-Petros w Zovuni w Armenii. Problem genezy kościoła w typie sali kopułowej, RH 51 (2003) z. 4, 214. 
wnioskować, że nie służyły one wyłącznie do artykulacji powierzchni, lecz podtrzymywały przekrycie bocznych portyków.

Nad przęsłem centralnym zastosowano rozwiązanie przypominające swą ideą i kształtem kopułę, jednak ze względów konstrukcyjnych rzeczywistą kopułą nie będące. Poświęcę mu więcej uwagi w dalszej części.

Do wnętrza prowadziły cztery wejścia, po jednym od zachodu i południa oraz dwoje drzwi od północy. Północną ścianę kościoła wyróżnia poza tym bogatsza dekoracja architektoniczna. Składały się na nią kolumny uwięzłe (na pozostałych elewacjach zastosowano pilastry) oraz dwa bogato dekorowane plastycznie portale ujmujące wejścia. $Z$ dwóch pozostałych wejść portalem ujęto jedynie drzwi zachodnie (il. 4). Wnętrze oświetlały rozmieszczone na trzech poziomach liczne okna różnej wielkości, wszystkie zamknięte od góry półkolistymi lub podkowiastymi łukami.

4. Dekoracja architektoniczna. Bogata, jak na tradycję armeńską, reliefowa dekoracja architektoniczna skoncentrowana była głównie na zewnątrz kościoła, na elewacjach, w portalach oraz na kapitelach i bazach podpór. Szczegółowe jej omówienie nie jest konieczne dla tematu, ograniczę się zatem do stwierdzenia, że wśród motywów zdobniczych znalazły się - zastosowane głównie w kapitelach - liście akantu o różnym stopniu stylizacji, kombinacje torusów i trochilusów w bazach podpór i gzymsach oraz kilka wyobrażeń krzyża równoramiennego ujętego tondem. Poziomą artykulację zewnętrznych powierzchni ścian tworzyły dwa szerokie, trójpasmowe gzymsy o podobnym profilu. Dolny przebiegał w sposób ciagły ponad podporami portyków i okalał otwory okienne i archiwoltę początkującą wspomnianą wyżej eksedrę przy północnym aneksie. Drugim gzymsem obwiedziono wieniec murów oraz trzy frontony - w elewacji zachodniej oraz w środkowych przęsłach naw bocznych.

5. Interpretacja. Badania architektoniczne Toramanjana dowiodły jednoznacznie, że ówczesna postać budowli była efektem kilku faz konstrukcyjnych. Jesteśmy w stanie wyodrębnić je z dużym prawdopodobieństwem.

Odnotować należy przede wszystkim użycie dwojakiego rodzaju materiału. Dolną partię murów zachodniego, północnego i południowego wzniesiono $\mathrm{z}$ różowego tufu. W wyższych częściach użyto natomiast tufu żółtego ${ }^{17}$. Granica między tymi strefami przebiegała tuż nad archiwoltami najniżej położonych otworów okiennych. Tuf żółty posłużył także do wzniesienia wschodniej części kościoła - absydy i flankujących ją pomieszczeń bocznych oraz do utworzenia dodatkowej, pojedynczej warstwy kamieniarki, nałożonej na dolne partie ścian północnej, zachodniej i południowej, i niezwiązanej konstrukcyjnie $\mathrm{z}$ ich wątkiem. Warstwa ta sięgała do wysokości wtopionych w nią kolumn i pilastrów, i tworzyła wraz z nimi oparcie dla przekrycia portyków. Jej górny

${ }^{17}$ Por. Khatchatrian, Architecture arménienne, s. 51n. 
kraniec pokrywał się ze wspomnianym wyżej szerokim gzymsem obiegającym elewacje północną, zachodnią i południową.

Osobny problem wiąże się z czterema filarami wewnątrz kościoła (il. 5). Ich nieregularny kształt powstał w wyniku przekształceń stwierdzonych przez Toramanjana $^{18}$ i przeanalizowanych przez Strzygowskiego ${ }^{19}$. Celem zmian było nadanie przęsłu centralnemu kwadratowego kształtu, niezbędnego do posadowienia konstrukcji kopułowej. Pierwotne przęsło miało kształt prostokątny, o czym świadczą dwie pary pilastrów na ścianach bocznych. Z ich rozmieszczenia wnioskować możemy, że także dwa pozostałe przęsła nawy głównej były prostokątami. Całkowicie nieznana pozostaje natomiast pierwotna forma wschodniego zakończenia budowli, z której nie zachowały się żadne ślady. Khatchatrian sugeruje istnienie w tym miejscu płytkiej, prostokątnej wnęki o szerokości równej nawie głównej (il. 7).

Różnice w materiale, niespójność konstrukcyjna między murami korpusu i portykami oraz przekształcenie filarów wskazują na dwa, a być może nawet trzy okresy w funkcjonowaniu budowli. Dopuszczają to wszyscy uczeni. Sekwencja wydarzeń mogła wyglądać następująco.

a) Faza I - świątynia pogańska. W Armenii zachowała się tylko jedno sanktuarium przedchrześcijańskie, świątynia w Garni, letniej rezydencji Arsacydów ${ }^{20}$. Jednak ten peripteros $\mathrm{w}$ typie rzymskim diametralnie odbiegał pod względem formy od innych sanktuariów, dostosowanych z pewnością do wymogów tamtejszej religii państwowej. Był nią mazdeizm z charakterystycznymi dlań obiektami kultu w postaci świątyń i ołtarzy ognia ${ }^{21}$. Ze źródeł historycznych wiemy, dlaczego żadna z tych budowli nie przetrwała we względnie pełnej postaci. W pierwszych dziesięcioleciach IV w., bezpośrednio po oficjalnej chrystianizacji, zostały zniszczone ${ }^{22}$. Nie znaczy to jednak, że nie zachowały się jakieś ich fragmenty. Taką pozostałością z czasów pogańskich mogła być krepidoma w Tekor. Ta wyjątkowo wysoka konstrukcja nie ma analogii w ówczesnej chrześcijańskiej architekturze armeńskiej. Zbliżoną wysokość osiągnęły jedynie 6-stopniowe podstawy bazyliki w Ereruk ${ }^{23}$

\footnotetext{
${ }^{18}$ Por. Toramanjan, Nyut'er Hayakakan, I, s. 198-200.

${ }^{19}$ Por. Strzygowski, Die Baukunst der Armenier, I, s. 337n.

${ }^{20}$ Por. A. Sahinian, Noveaux matériaux concernant l'architecture des constructions antiques de Garni, REArm NS 6 (1969), 181-200; D. Próchniak, Przedchrześcijańska architektura sakralna Armenii. Próba rekonstrukcji w świetle źródet materialnych i przekazów literackich, RH 31 (1983) z. 4, 28-32.

${ }^{21} \mathrm{Na}$ temat przedchrześcijańskich wierzeń Armeńczyków zob. m.in. A. Carrière, Les huit sanctuaires de l'Arménie païenne d'après Agathange et Moïse de Khorène, Paris 1899, 11-15 i passim; N. Adontz, Les vestiges d'un ancien culte en Arménie, „Annuaire de l'Institut de Philologie et d'Histoire Orientales et Slaves" 4 (1936) 511-515 i passim; Grousset, L'Histoire de l'Arménie, s. 117 120; J. Karst, Mythologie arméno-caucasienne et hétito-asianique, Strasbourg - Zurich 1948, 3-6 i 26-28; D.M. Lang, Armenia kolebka cywilizacji, thum. T. Szafar, Warszawa 1975, 121-123.

${ }^{22}$ Szerzej por. Próchniak, Przedchrześcijańska architektura sakralna Armenii, s. 33n.

${ }^{23}$ Por. P. Paboudjian - A. Alpago-Novello, La basilica di Ererouk, Documenti di architettura armena 9, Milano 1977, 5n.
} 
i kościoła jednonawowego $\mathrm{w}$ Tanahat ${ }^{24}$. W obu przypadkach zadecydowało o tym jednak ukształtowanie terenu, lekko nachylonego, w wyniku czego na niektórych odcinkach ilość stopni zredukowano. Kościół Surb Sargis zbudowano na całkowicie płaskim podłożu, wysokość podbudowy musiała więc być zamierzona. Na podobne sugestie pozwala również jej niemal kwadratowy kształt, zdecydowanie rzadki w armeńskiej architekturze, zdominowanej przez budowle o wyraźnie wydłużonych proporcjach ${ }^{25}$. W Tekor mogło zatem istnieć sanktuarium mazdejskie podobne do również kwadratowych w planie świątyń partyjskich - np. przy pałacu w Hatrze (II w.) ${ }^{26}$, lub sasanidzkich - np. w Biszapur (III w. $)^{27}$. Mógł tam też stać jedynie ołtarz ognia osłonięty charakterystycznym dla architektury perskiej czteropodporowym baldachimem w typie czachar-tak, znanym z zabytków w Neisar (II w.) i Rabat-i-Safid (pocz. III w. $)^{28}$. Najprawdopodobniej konstrukcja tego rodzaju istniała w czasach przedchrześcijańskich także we wspomnianym, nieodległym mieście Ani ${ }^{29}$.

b) Faza II - kościół bezkopułowy. Źródła historyczne informują wielokrotnie, że tereny i dobra sanktuariów pogańskich przekazywano w użytkowanie Kościołowi. W niektórych z tych miejsc powstały świątynie chrześcijańskie. Np. Zenob z Glag w Patmut 'iwn Taraun pisze o wzniesieniu kościoła na miejscu świątyni Temedre, dodając przy tym, że zachowano proporcje pierwotnej budowli ${ }^{30}$. Tak mogło się zdarzyć również w Tekor. Przy wznoszeniu kościoła wykorzystano - co wydaje się z różnych względów całkowicie uzasadnione - monumentalną, wysoką krepidomę pogańską. Jej kwadratowy plan jest dobrym wytłumaczeniem dla wyjątkowo zwartego i krótkiego obrysu budowli. Pogański rodowód mogły też mieć wspomniane wyżej dolne fragmenty murów z różowego tufu. Kościół miałby układ trójnawowej i trójprzęsłowej bazyliki w typie orientalnym, a więc o nawach przesklepionych kolebkami ${ }^{31}$. Nic nie możemy powiedzieć o jego wschodnim zakończeniu. Nie mamy też żadnych podstaw umożliwiających precyzyjne datowanie. Terminem ante quem non jest rok 301, w którym nastąpiła chrystianizacja Armenii. Termin

\footnotetext{
${ }^{24}$ Por. Cuneo, Architettura armena, I, s. 406.

${ }^{25}$ Por. tenże, Le basiliche paleocristiane armene, „Corsi di cultura sull'arte ravennate e bizantina" 20 (1973) 217-239.

${ }^{26}$ Por. R. Ghirshman, Iran. Parthes et Sassanides, Paris 1962, 36n.

${ }^{27}$ Por. E. Porada, Ancient Iran, London 1964, 198n; A.U. Pope, Persian architecture, London 1965, 57-61.

${ }^{28}$ Por. A. Godard , L'art de l'Iran, Paris 1962, 208n; Pope, Persian architecture, s. 50.

${ }^{29}$ Por. D. Próchniak, O kapłanach i ołtarzach w późnoantycznej Armenii, w: SymKaz 6, 2008, 67-73.

${ }^{30}$ Por. w przekładzie francuskim: Zénob de Glag, Histoire de Daron, trad. V. Langlois, w: Collection des Historiens ancien et morernes de l'Arménie, publiée par V. Langlois, I, Paris, 1867, 348.

${ }^{31} \mathrm{Na}$ temat inny armeńskich bazylik w typie orientalnym por. D. Próchniak, Wczesnochrześcijańskie kościoły bezkopułowe w Armenii. Główne cechy i ewolucja typologiczna układu architektoniczno-przestrzennego, RH 39-40 (1991-1992) z. 4, 17-34.
} 
post quem non - przełom V i VI stulecia - możemy wskazać w oparciu o analizę przytoczonej wyżej inskrypcji fundacyjnej.

c) Faza III - kościól kopułowy. Najważniejszym bezspornie zjawiskiem w kształtowaniu ostatecznego charakteru i cech architektury sakralnej wschodniego chrześcijaństwa była powolna dążność do centralizacji układu przestrzennego, podporządkowanego dominującej w bryle budowli kopule. W procesie tym ogniwem bardzo znaczącym jest - moim zdaniem - III faza kościoła w Tekor, w której nadano mu ostateczną, opisaną wyżej postać (il. 1,2 i 6). Przypomnijmy - ukształtowano wówczas część wschodnią złożoną z absydy i bocznych pomieszczeń, dodano portyki wzdłuż trzech elewacji, a przede wszystkim wprowadzono konstrukcję o charakterze kopułowym, co - jak już wiemy - wymusiło przekształcenie czterech filarów. Główny problemem inżynieryjnym związanym z posadowieniem kolistej kopuły nad kwadratowym przęsłem jest redukcja naroży kwadratu, co odbywa się na dwa kanoniczne sposoby - albo za pomocą tromp, albo dzięki zastosowaniu pendentywów. Rozwiązaniem ewolucyjnie wcześniejszym i mniej doskonałym były trompy. I właśnie niewielkie, monolitowe trompy odnajdujemy w Tekor (il. 8). Przy ich pomocy kształt centralnego przęsła sprowadzono do oktogonu o bokach przemiennie dłuższych i krótszych. Powyżej umieszczono osiem nachylonych do środka kamiennych płyt w kształcie trapezu, mniejszych i większych. Zamocowano je na zmianę - raz dłuższą, raz krótszą podstawą ku górze. Ich wielkość dobrano w ten sposób, by górne krawędzie miały tę samą długość. W ten sposób powstała ośmioboczna nasada, na której umieszczono niewielką czaszę kopuły. Od strony zewnętrznej konstrukcję złożoną z trapezowych płyt ukryto w sześciennej obudowie (il. 2). Czasza kopuły mogła pierwotnie mieć, zgodnie z wczesnochrześcijańska, armeńską tradycja, poszycie z dachówek, mocowanych bezpośrednio na jej grzbiecie przy użyciu zaprawy ${ }^{32}$. Stożkowo-harmonijkowa forma dachu widoczna na fotografiach z początku XX w. jest niewątpliwie późniejsza. Dachy tego rodzaju pojawiły się w Armenii dopiero w IX stuleciu, przede wszystkim w budowlach fundowanych wówczas przez ród Pahlawunich ${ }^{33}$. Niewykluczone, że przeprowadzono wówczas w kościele jakieś prace restauracyjne. Zgadzałyby się one czasowo z wydarzeniami wymienionymi we wspomnianych inskrypcjach władców bagratydzkich.

Trompy w Tekor są jednym z najwcześniejszych przypadków użycia tego typu elementów w całym Orbis christianus. Uważam, że sytuują one architekturę Armenii w czołówce przemian prowadzących do ukonstytuowania się kościołów kopułowych. Potwierdzają to dwa inne - współczesne, lub

${ }^{32}$ Por. D. Próchniak, Techniki budowlane $w$ architekturze Armenii w okresie późnego antyku i wczesnego średniowiecza, w: Toruńskie studia o sztuce Orientu, red. J. Malinowski-M. Wojtczak, II, Toruń 2005, 96-98.

${ }^{33}$ Por. P. Cuneo, Le couvent de Marmašēen et l'école architecturale d'Ani, REArm NS 23 (1992) 420; P. Donabédian, L'École d'architecture d'Ani, w: Ani. Capitale de l'Arménie en l'an mil. Paris, Pavillon des Arts, 7.02.-13.05. 2001 (katalog wystawy), éd. R.H. Kévorkian, Paris 2001, 189n. 
nieco późniejsze od Tekor - armeńskie przykłady: datowana między końcem V a przełomem VI/VII w. ostatnia faza jednonawowego kościoła Surb Połos-Petros w Zowuni na Wyżynie Ararackiej ${ }^{34}$, a zwłaszcza mała budowla, być może kaplica grobowa, na cmentarzu w miejscowości Wochdżaberd, ok. 20 km na północ od Erewania, datowana na V/VI w. ${ }^{35}$, której reszki odkrył Tokarski podczas wykopalisk w latach 1961-1962 (il. 9 i 10) ${ }^{36}$. Miała ona plan kwadratu z ukrytą w trójbocznej obudowie absydą od strony wschodniej. W jej ruinach odnaleziono dwie monolitowe trompy o lekko wklęsłej powierzchni czołowej (il. 11). Ze względu na niewielkie rozmiary całkowita redukcja naroży kwadratu, a tym samym utworzenie przy ich użyciu kolistej nasady kopuły okazało się niemożliwe. Pozwoliły natomiast na przekształcenie kwadratu w ośmiobok o wyraźnie zróżnicowanej długości boków i czterech zaokrąglonych narożach. Zamiast kopuły skonstruowano - jak uważa Tokarski - przekrycie złożone z ośmiu sferycznie wygiętych trójkątnych segmentów dwojakiej wielkości, które umocowano przemiennie w zależności od długości boków ośmiokąta, stanowiących ich podstawę (il. 12). Podobieństwo do konstrukcji kopułowej w Tekor wydaje się ewidentne.

\section{$* * *$}

W podsumowaniu chciałbym odwołać się do podtytułu niniejszego tekstu. Co łączy kościoła Surb Sargis z architekturą bizantyńską? Odpowiedź jest prosta - zarówno funkcja, jak i krzyżowo-kopułowa forma, mimo cech własnych tekorskiej budowli. Mam na myśli ukształtowanie części absydalnej i portyki wzdłuż elewacji. Natomiast związek z Persją tkwi w sferze technicznej. Elementem perskim, o genezie partyjsko-sasanidzkiej, są trompy. Stosowano je na Wyżynie Irańskiej znacznie wcześniej niż w domenach chrześcijańskich ${ }^{37}$. Służyły tam do przekrywania kwadratowych pomieszczeń pałacowych i świątynnych. Miały też zastosowanie w murowanych baldachimach nad ołtarzami ognia. Jako przykład podać można pochodzący z II w., a więc bardzo wczesny, czachar-tak w Neisar. Z Persji dotarły do Armenii. Być może jeszcze przed jej chrystianizacją, chociaż archeologicznym tego potwierdzeniem z przyczyn wyżej opisanych nie dysponujemy. W Armenii zadomowiły się na długo i powszechnie. Najpierw w Tekor, Zowuni, Wochczaberd. Potem $\mathrm{w}$ dziesiątkach innych kościołów ${ }^{38}$. Stały się podstawowym, najczęściej

${ }^{34}$ Por. Próchniak, Wczesnochrześcijański kościót Surb Połos-Petros, s. 223n.

${ }^{35}$ Por. F. Gandolfo, Armenien und Georgien, w: Spätantike und frühes Christentum, hrsg. B. Brenk, Frankfurt am Main - Berlin - Wien 1977, 203.

${ }^{36}$ Н. Токарский, Джрвеж (II). Вохджаберд, Археологические раскопки в Армении 11, Ереван 1964, 48-67.

${ }^{37}$ Por. A.U. Pope, Introducing Persian architecture, Teheran 1976, 33; D. Huff, Architecture sassanide, w: Splendeur des Sassanides. L'empier perse entre Rome et la Chine [224-642]. Bruxelles, Musées royaux d'Art et d'Histoire, 12.02. - 25.04. 1993 (katalog wystawy), Bruxelles 1993, 45-61.

${ }^{38}$ Szerzej na temat zastosowania tromp w architekturze armeńskiej por. D. Próchniak, Inwe- 
stosowanym elementem w konstrukcjach kopułowych. Z Armenii powędrowały do Bizancjum.

\section{THE SURB SARGIS (ST. SERGEI'S) CHURCH IN TEKOR (ARMENIA): BETWEEN PERSIA AND BYZANTIUM}

\section{(Summary)}

The Surb Sargis (St. Sergei's) church in Tekor, in the Shirak region of the present-day Turkey, is nowadays in total ruin. Fortunately, before its destruction by the 1911 earthquake, it had been extensively studied (e.g. by T. Toramanian and J. Strzygowski) and the documentation preserved allows us to treat it as one of the most important early-Christian buildings in both Armenia and the whole Orbis Christianus (Fig. 1-3).

It is highly probable that the church was built at the site of an earlier pagan temple, utilising the former building's tall 9-step crepidoma. Between the beginning of the $4^{\text {th }}$ and the ending of the $5^{\text {th }}$ century a three-nave basilica without a dome was built on the earlier base, only to be thoroughly rebuilt in the years 478-504 (dating based on the inscription at the lintel of the western portal; Fig. 4). After the rebuilding, the church acquired its 9-square structure designed by 3 naves and 3 bays. The central bay was covered with a small cupola, or rather, a cupola-structure (Fig. 5 and 7). Taking into account the contemporary state of research one may suppose that this innovative construction is the earliest known link in the process of emerging of the cross-cupola plan of churches, dominating till today in the church architecture of Eastern Christianity.

The reduction of the corners of the central bay - in order to adjust its square shape to the circular base of the dome - was achieved by the construction of four small squinches (Fig. 8). This solution was most probably taken over from the $2^{\text {nd }}-3^{\text {rd }}-$ century architecture of Persia, with which the pre-Christian Armenia had long maintained strong and varied contacts.

Apart from the Tekor basilica, squinches were also used in two other buildings on the Ararat Upland near Erevan: in the small grave chapel at the Voghjaberd cemetery ( $5^{\text {th }}-6^{\text {th }}$ century; Fig. 9-12) and in the one-nave church Surb PoghosPetros (St. Paul and Peter's) in Zovuni (between the ending of the $5^{\text {th }}$ and the turning of the $6^{\text {th }}$ and $7^{\text {th }}$ centuries). These examples allow one to treat Armenia as a bridge between the architecture of Persia and Byzantium, where similar constructions appeared and spread widely in later periods.

Translated by Barbara Klonowska

stycyjna działalność biskupów i katolikosów armeńskich, w: SymKaz, 3, 2002, 140; tenże, Techniki budowlane w architekturze Armenii, s. 90-94. 
Key words: Armenian early-Christian architecture, earliest churches with domes, squinch dome genesis.

Słowa kluczowe: wczesnochrześcijańska architektura Armenii, najwcześniejsze kościoły kopułowe, geneza kopuły na trompach.

\section{BIBLIOGRAFIA}

Adontz N., Les vestiges d'un ancien culte en Arménie, „Annuaire de l'Institut de Philologie et d'Histoire Orientales et Slaves" 4 (1936) 501-515.

CARRIÈRE A., Les huit sanctuaires de l'Arménie païenne d'après Agathange et Moïse de Khorène, Paris 1899.

Cuneo P., Architettura armena dal quarto al diciannovesimo secolo, I-II, Roma 1988.

Cuneo P., Le basiliche paleocristiane armene, „Corsi di cultura sull'arte ravennate e bizantina" 20 (1973) 217-239.

Cuneo P., Le couvent de Marmašēen et l'école architecturale d'Ani, REArm NS 23 (1992) 419-471.

Donabédian P., L'École d'architecture d'Ani, w: Ani. Capitale de l'Arménie en l'an mil. Paris, Pavillon des Arts, 7.02.-13.05.2001 (katalog wystawy), éd. R.H. Kévorkian, Paris 2001, 182-194.

Gandolfo F., Armenien und Georgien, w: Spätantike und frühes Christentum, hrsg. B. Brenk, Frankfurt am Main - Berlin - Wien 1977, 201-213.

GAndolfo F., Le basiliche armene IV-VII secolo, Studi di Architettura Medioevale Armena 5, Roma 1982.

Ghirshman R., Iran. Parthes et Sassanides, Paris 1962.

GodArD A., L'art de l'Iran, Paris 1962.

Grousset R., L'Histoire de l'Arménie des origins jusqu'à 1071, Paris 1947.

Huff D., Architecture sassanide, w: Splendeur des Sassanides. L'empier perse entre Rome et la Chine [224-642]. Bruxelles, Musées royaux d'Art et d'Histoire, 12.02.- 5.04.1993 (katalog wystawy), Bruxelles 1993, 45-61.

Karst J., Mythologie arméno-caucasienne et hétito-asianique, Strasbourg - Zurich 1948.

Khatchatrian A., Architecture arménienne du IVe au VIe siècle, Paris 1971.

KHATCHATRIAN A., Inscriptions et histoire des églises arméniennes, Ricerca sull'architettura armena 8, Milano 1974.

LANG D.M., Armenia kolebka cywilizacji, tłum. T. Szafar, Warszawa 1975.

Марр Н.Я., К датировке ктиторской надписи Текорского храма, „Христянский Восток” 3 (1914) 56-71.

Paboudjian P. - Alpago-Novello A., La basilica di Ererouk, Documenti di architettura armena 9, Milano 1977.

Pope A.U., Introducing Persian architecture, Teheran 1976.

Pope A.U., Persian architecture, London 1965.

Porada E., Ancient Iran, London 1964.

Próchniak D., Inwestycyjna działalność biskupów i katolikosów armeńskich, w: SymKaz 3, 2002, 131-161.

Próchniak D., O kapłanach i ołtarzach w późnoantycznej Armenii, w: SymKaz 6, 2008, 65-87.

Próchniak D., Przedchrześcijańska architektura sakralna Armenii. Próba rekonstrukcji w świetle źródeł materialnych i przekazów literackich, RH 31 (1983) z. 4, 27-41. 
PróchniaK D., Techniki budowlane $w$ architekturze Armenii w okresie późnego antyku $i$ wczesnego średniowiecza, w: Toruńskie studia o sztuce Orientu, red. J. Malinowski - M. Wojtczak, II, Toruń 2005, 73-106.

PróchniaK D., Wczesnochrześcijańskie kościoły bezkopułowe w Armenii. Główne cechy $i$ ewolucja typologiczna układu architektoniczno-przestrzennego, RH 39-40 (19911992) z. 4, 17-34.

Próchniak D., Wczesnochrześcijański kościót Surb Połos-Petros w Zovuni w Armenii. Problem genezy kościoła w typie sali kopułowej, RH 51 (2003) z. 4, 213-239.

Sahinian A., Noveaux matériaux concernant l'architecture des constructions antiques de Garni, REArm NS 6 (1969) 181-200.

Strzygowski J., Die Baukunst der Armenier und Europa, I-II, Wien 1918.

TeXIER Ch.F.M., Description de l'Arménie, de la Perse et de la Mésopotamie. Géographie, géologie, monuments anciens et modernes, I-II, Paris 1842-1852.

ThIERry N. - ThIERry M., Notes sur des monuments arméniens en Turquie (1964), REArm NS 2 (1965) 165-184.

ТокАРский Н., Архитектура древней Армении, Ереван 1961.

ТокАРский Н., Джрвеж (II). Вохджаберд, Археологические раскопки в Армении 11, Ереван 1964.

TORAMANJAn T., Nyut'er Hayakakan čartarapetut'yan patmut'yan (Materiaty do historii architektury Armenii; w j. armeńskim), I-II, Erevan 1942-1948.

\section{ANEKS}

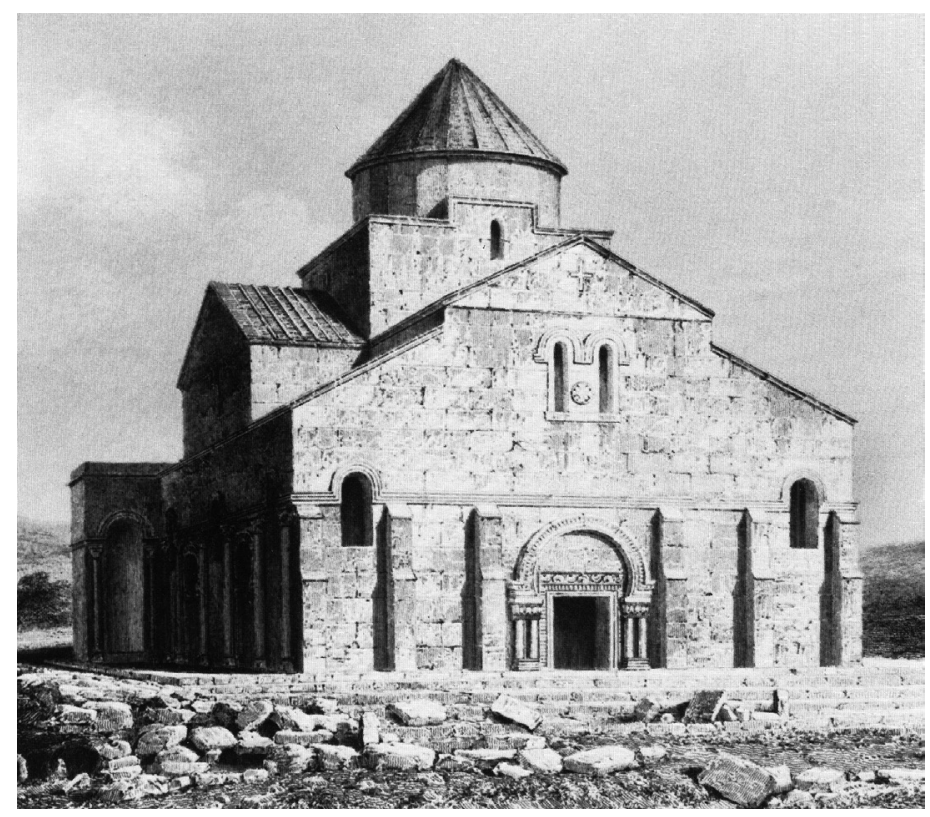

Il. 1. Tekor. Kościół Surb Sargis. Widok od zachodu. Rysunek Ch. Teriera. IV/V i XI wiek. Za: F. Gandolfo, Armenien und Georgien, w: Spätantike und frühes Christentum, hrsg. B. Brenk, Frankfurt am Main - Berlin - Wien 1977, il. 205. 


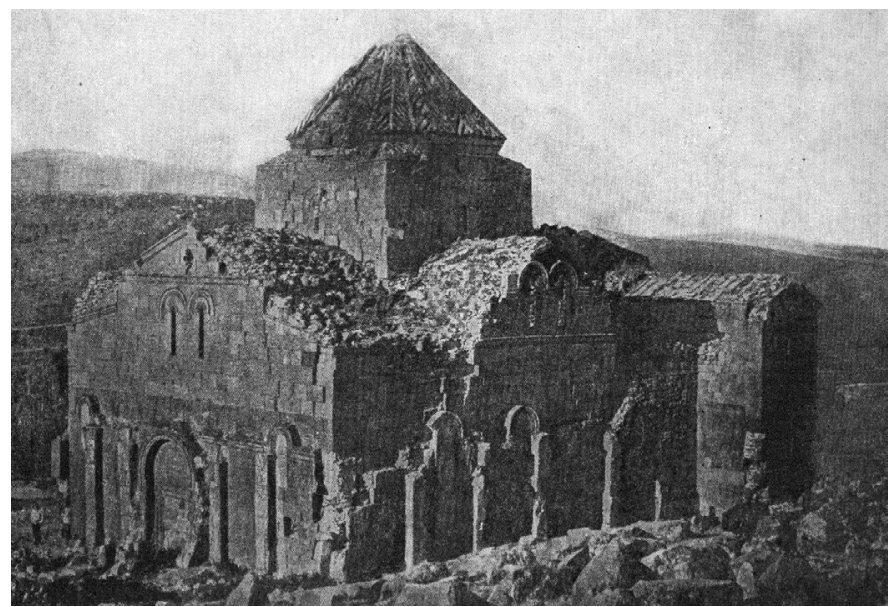

Il. 2. Tekor. Kościół Surb Sargis. Stan sprzed trzęsienia ziemi w 1911 rok. Za: H. Токарский, Архитектура древней Армении, Ереван 1961, il. 14.

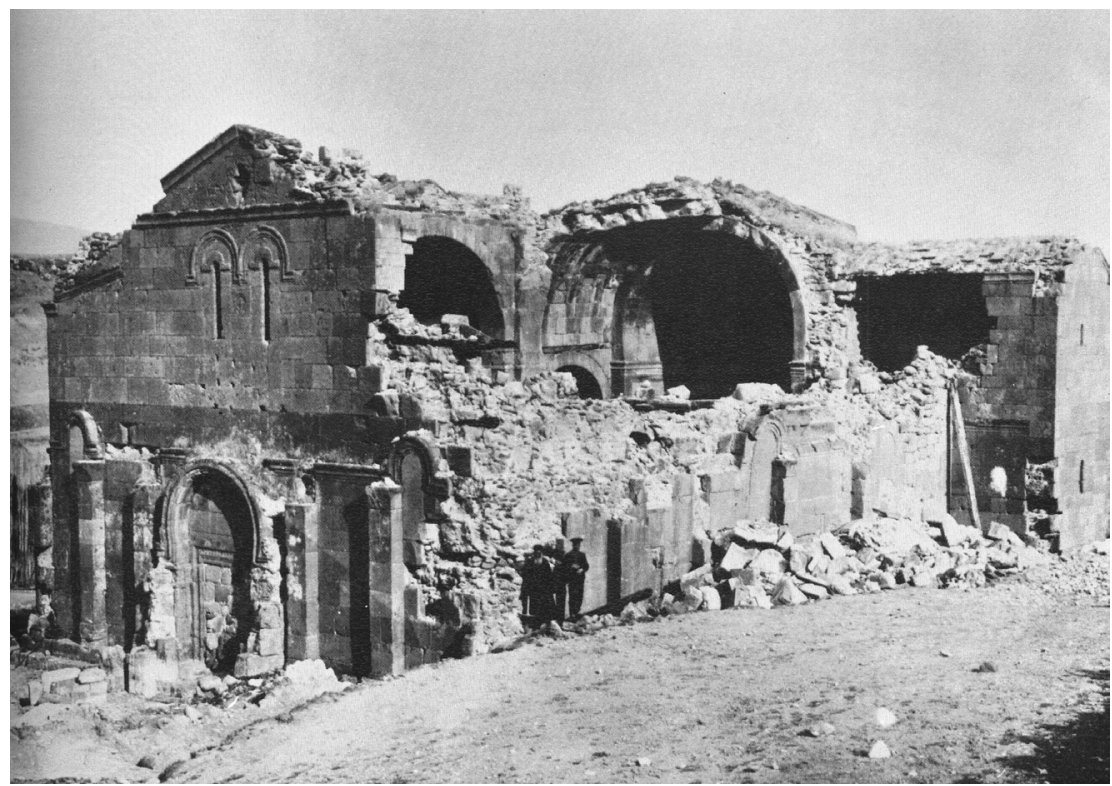

Il. 3. Tekor. Kościół Surb Sargis. Stan bezpośrednio po trzęsieniu ziemi. Za: J. Strzygowski, Die Baukunst der Armenier und Europa, I, Wien 1918, Abb. 382. 


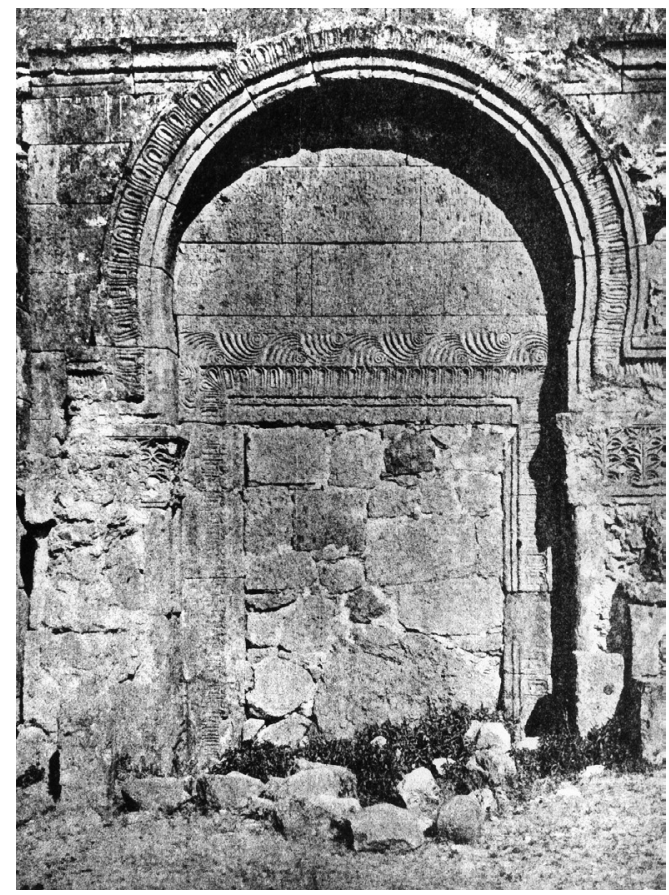

I1. 4. Tekor. Kościół Surb Sargis. Portal zachodni. Za: J. Strzygowski, Die Baukunst der Armenier und Europa, I, Wien 1918, Abb. 37.

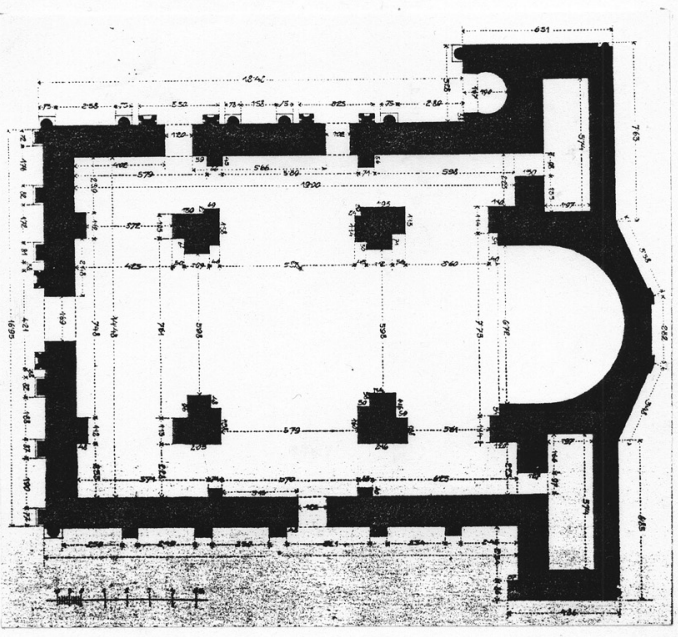

Il. 5. Tekor. Kościół Surb Sargis. Plan. Za: J. Strzygowski, Die Baukunst der Armenier und Europa, I, Wien 1918, Abb. 383. 


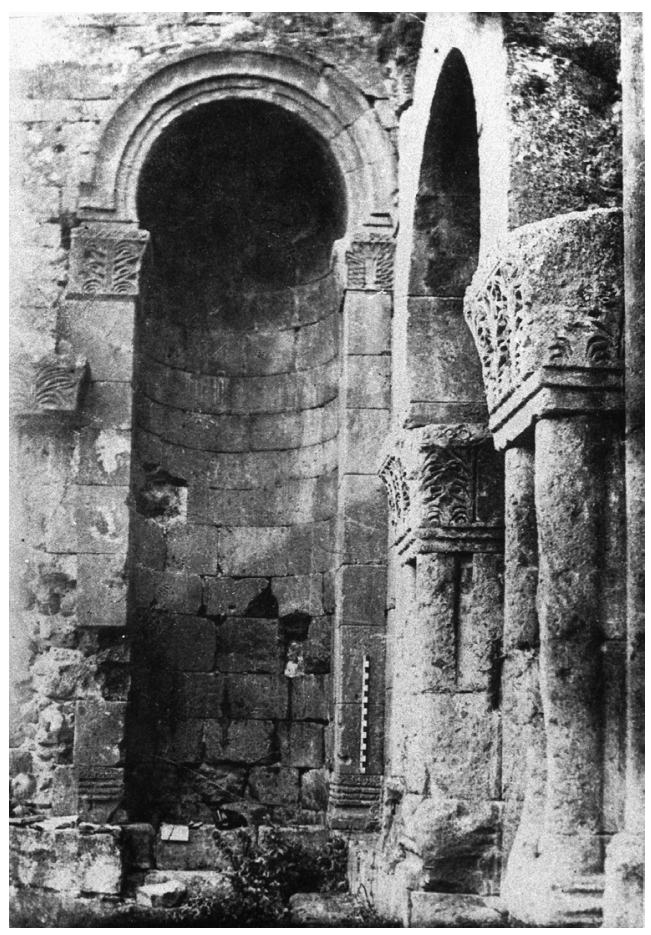

Il. 6. Tekor. Kościół Surb Sargis. Eksedra w murze zewnętrznym północnego pomieszczenia bocznego przy absydzie. Za: J. Strzygowski, Die Baukunst der Armenier und Europa, I, Wien 1918, Abb. 434.

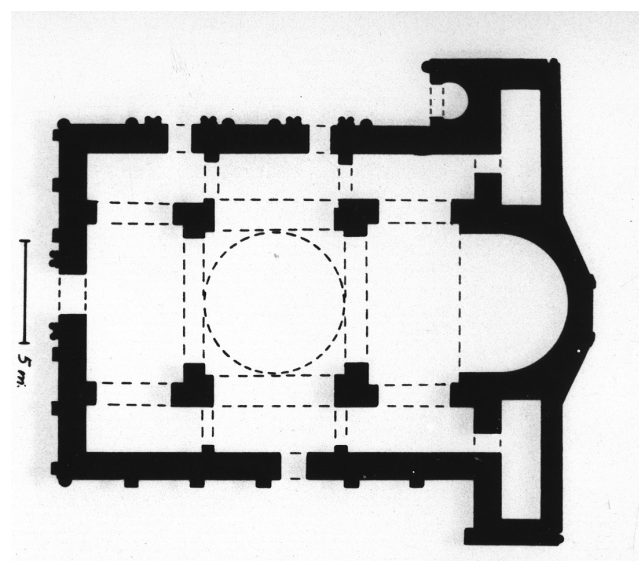

Il. 7. Tekor. Kościół Surb Sargis. Rekonstrukcja pierwotnego planu wg A. Khatchatriana. Za: A. Khatchatrian, Architecture arménienne du $I V^{e}$ au $V I^{e}$ siècle, Paris 1971, fig. 40. 


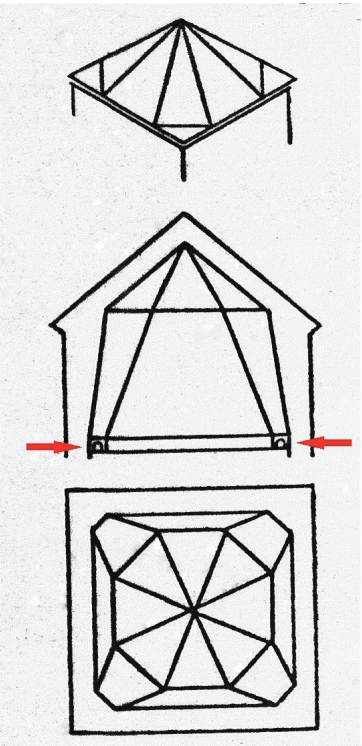

Il. 8. Tekor. Kościół Surb Sargis. Trompy w narożach konstrukcji kopułowej. Za: H. Токарский, Джрвеж (II). Вохджаберд, Археологические раскопки в Армении 11, Ереван 1964, рис. 29.

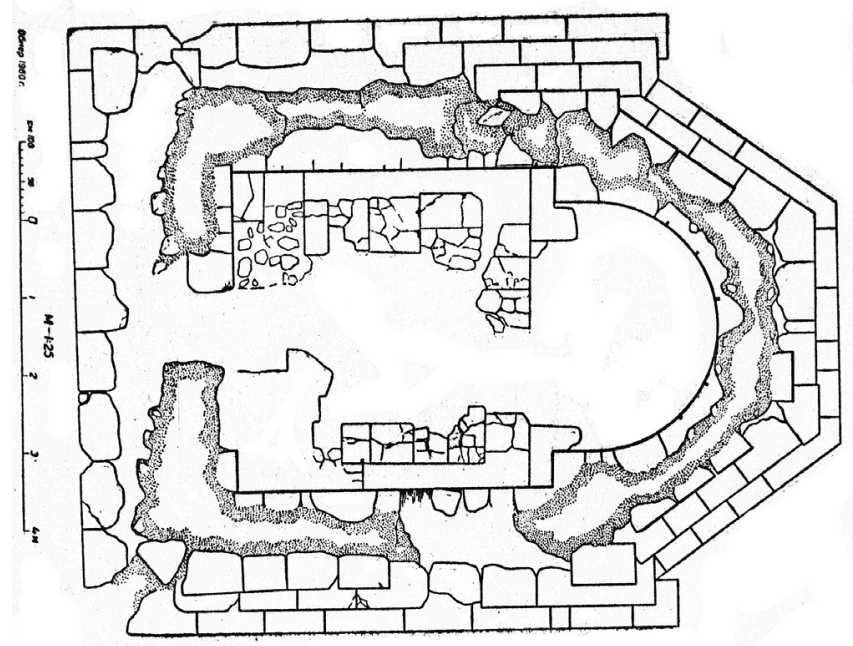

Il. 9. Wochdżaberd. Kaplica. Plan. Za: Н. Токарский, Джрвеж (II). Вохджаберд, Археологические раскопки в Армении 11, Ереван 1964, рис. 25. 


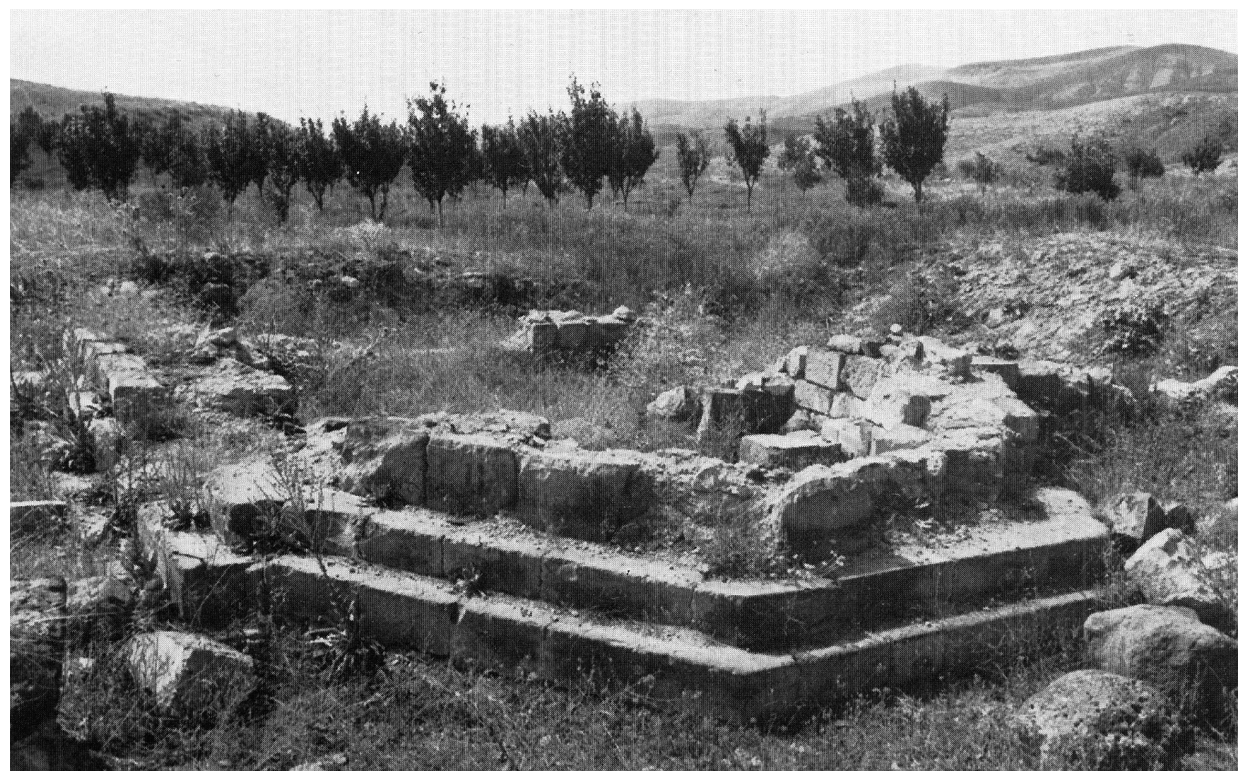

Il. 10. Woghdżaberd. Pozostałości kaplicy. Widok od wschodu. Za: F. Gandolfo, Armenien und Georgien, w: Spätantike und frühes Christentum, hrsg. B. Brenk, Frankfurt am Main - Berlin - Wien 1977, il. 203a.

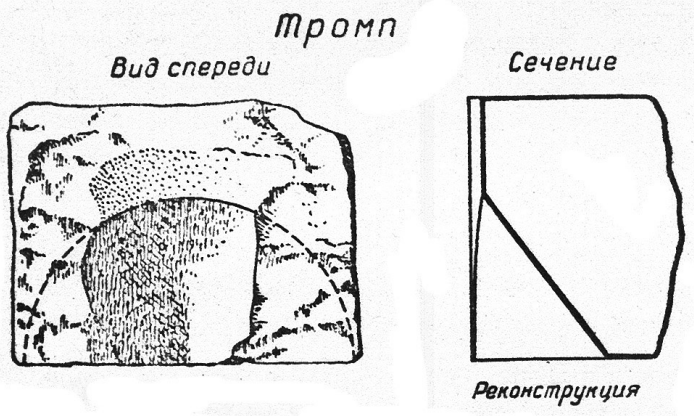

Il. 11. Wochdżaberd. Kaplica. Rysunek trompy odnalezionej w ruinach. Za: H. Токарский, Джрвеж (II). Вохджаберд, Археологические раскопки в Армении 11, Ереван 1964, рис. 28. 

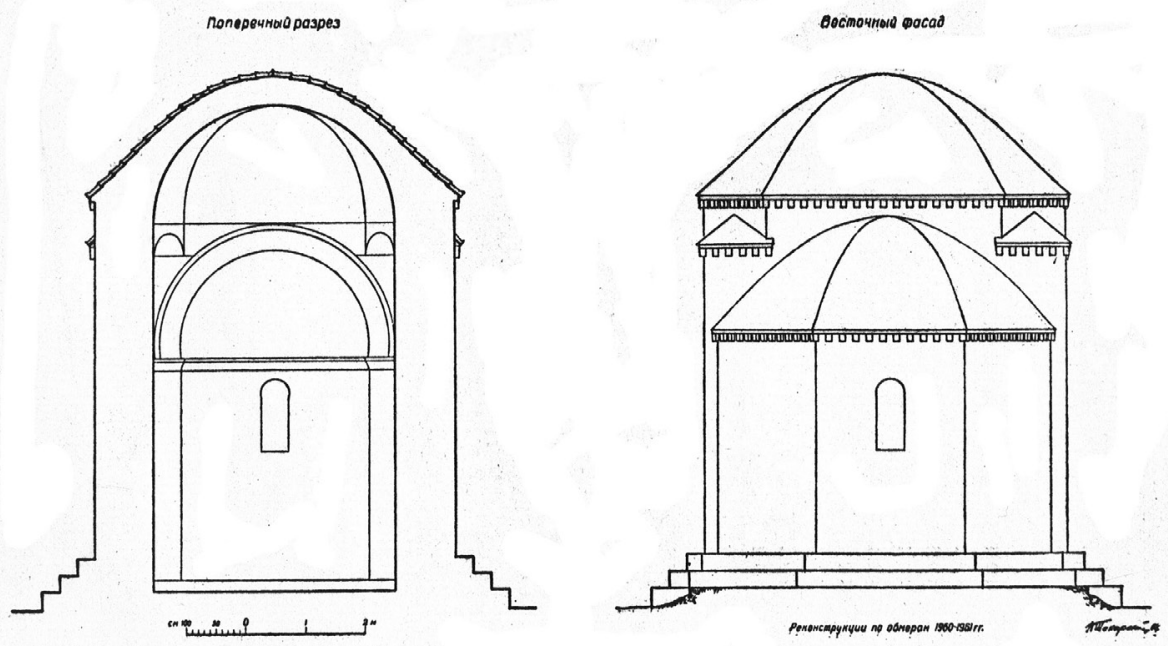

Il. 12. Wochdżaberd. Kaplica. Rekonstrukcja N. Tokarskiego. Za: Н. Токарский, Джрвеж (II). Вохджаберд, Археологические раскопки в Армении 11, Ереван 1964, рис. 33. 